\title{
Political Finance Regulation and Reform in New South Wales: Towards a Fairer System?
}

\author{
ZIM NWOKORA \\ Deakin University \\ MAlCOLM Anderson, JoO ChEONG THAM \\ University of Melbourne \\ ANIKA GAUJA AND STEPHEN MILLS \\ University of Sydney \\ NARELLE MiRAGLIOTTA \\ Monash University
}

\begin{abstract}
In recent years the regulation of political finance in Australia has moved from systems of laissez-faire to systems of enhanced regulation, which aim to curb the scale and influence of donations. This article examines political finance regulation in New South Wales - the jurisdiction that has seen the most significant transformation of its regulatory setup - to assess whether and how the new regulations have affected donations to political parties in the state. We find, based on analysis of the pattern of donations before and after the reforms, that the regulations have made the financing system fairer and thus improved the quality of democracy in the state.
\end{abstract}

The relationship between "money" and "politics" has been a topic of longstanding interest to researchers from law, political science and economics. ${ }^{1}$ Studies of Australian political finance highlight the prevalence, until recently, of regulations that were relatively "laissez-faire" in comparison to those in other established democracies. This difference, argued Graeme Orr, reflected a "lackadaisical" attitude toward regulation in Australian political culture. ${ }^{2}$ In the past decade, however, this landscape has changed considerably with several jurisdictions within the Australian federation introducing reforms to tighten political financing, including: requirements for greater transparency; bans on donations from certain industries, such as gambling and liquor businesses; and restrictions on the amounts that can be donated to, or spent by, political parties and candidates. ${ }^{3}$

These initiatives have been driven, to a large extent, by the growing sense that a laissez-faire approach was no longer working. It sustained the opacity of political financing, with politicians regularly facing conflicts of interest and critics warning that

\footnotetext{
${ }^{1}$ See, for instance, Burton A. Abrams and Russell F. Settle, "The Economic Theory of Regulation and Public Financing of Presidential Elections", Journal of Political Economy, Vol. 86, 2 (1978), pp.245-257; Keith Ewing and Samuel Issacharoff, eds., Party Funding and Campaign Financing in International Perspective (Oxford, 2006); Raymond La Raja, Small Change: Money, Political Parties, and Campaign Finance Reform (Ann Arbor, 2008); Pippa Norris and Andrea Abel Van Es, Checkbook Elections? Political Finance in Comparative Perspective (New York, 2016); Graeme Orr, "Party Finance Law in Australia: Innovation and Enervation", Election Law Journal, Vol.15, 1 (2016), pp.58-70; Joo-Cheong Tham, Money and Politics: The Democracy We Can't Afford (Kensington, 2010); Michael Pinto-Duchinsky, "Financing Politics: A Global View", Journal of Democracy Vol. 13, 4 (2002), pp.69-86; David M. Primo and Jeffrey Milyo, "Campaign Finance Law and Political Efficacy: Evidence from the States", Election Law Journal, Vol. 5, 1 (2006), pp.23-39.

2 Graeme Orr, "Political Disclosure Regulation in Australia: Lackadaisical Law", Election Law Journal, Vol 6, 1 (2007), pp.72-88.

${ }^{3}$ Orr, "Party Finance Law in Australia", pp.58-70.
}

This is the author manuscript accepted for publication and has undergone full peer review but has not been through the copyediting, typesetting, pagination and proofreading process, which may lead to differences between this version and the Version of Record. Please cite this article as doi: 10.1111/ajph.12534 
democracy was being "corrupted" by corporate influence. ${ }^{4}$ Furthermore, the financing system was attacked for its inefficiency: it made elections wastefully expensive by facilitating an "arms race" between the major parties (the Australian Labor Party and the Liberal-National Coalition). With both parties scrambling for funds to "get ahead" or "stay ahead", their fortunes remained relatively stable over time, but the cost of campaigns, and the amount of time that politicians devoted to fundraising, were massively inflated..$^{5}$ And the financing system handicapped the minor parties, which many citizens viewed as being unfair. ${ }^{6}$

In light of these concerns, parliaments across the federation have sought to enhance the regulation of political finance to address these problems. Thus it is important to consider whether, and to what extent, the reforms have succeeded in such terms - in short, have they made political financing fairer and thereby improved the quality of democracy? This article undertakes such an assessment, focusing on the regulations enacted in New South Wales since 2008. This state provides an ideal case study to understand the effects of political finance regulation and reform. It has been the site of high-profile scandals that have thrown political finance issues into the media spotlight. ${ }^{7}$ The state's importance in national politics, due to its large population and economy, has amplified this attention. Moreover, New South Wales has been the "pioneer" jurisdiction in terms of political finance regulation: it was the first to introduce party registration, public funding and disclosure of political donations, and its replacement of what had been a laissez-faire approach to donations and election spending has been more rapid and comprehensive than elsewhere, perhaps because of the perceived severity of the challenge in this state.

Although the purported impact of political financing in New South Wales receives significant media attention, there have been only a few in-depth analyses of these reforms. ${ }^{8}$ Moreover, this previous work has focused on tracking trends over time and devotes little attention to teasing out the normative implications of these developments. This study seeks to address this gap. While developing our understanding of "what has happened?" in the New South Wales political finance system, it attempts to clarify "what it all means?" by situating these trends within a sensible normative framework. As well as adding this distinctive angle to the Australian debate about political finance, the study also contributes to the comparative literature on this subject. Firstly, it bears on debates between regulatory "optimists", who believe that well-crafted regulations

\footnotetext{
${ }^{4}$ See, for instance, Warwick Smith, "Political Donations Corrupt Democracy in Ways You Might Not Realise", The Guardian, 11 September 2014; Anika Gauja, "Election Rules, Public Funding and Private Donations", in David Clune and Rodney Smith, eds, From Carr to Keneally: Labor in Office in NSW 1995-2011 (Sydney, 2012), pp.233-247.

${ }^{5}$ The introduction of public funding appears to have fuelled, rather than alleviated, this trend. See Malcolm Anderson and Joo-Cheong Tham, "Dynamics of Electoral Expenditure and the 'Arms Race' Thesis: The Case of New South Wales", Australian Journal of Political Science, Vol. 49, 1 (2014), pp.84-101; Iain McMenamin, If Money Talks, What Does it Say? (Oxford, 2013), p.88.

${ }^{6}$ Zim Nwokora, "Sceptical Partisans: How Citizens Think about Political Finance", Australian Journal of Political Science, Vol. 50, 1 (2015), pp.73-92.

7 See, for instance, Marian Sawer, "Follow the Money: The Difficult Path to Political Donation Reform", The Conversation, 6 July 2015.

${ }^{8}$ Malcolm Anderson, Joo-Cheong Tham, Zim Nwokora, Anika Gauja, Stephen Mills and Narelle Miragliotta, "Less Money, Fewer Donations: The Impact of New South Wales Political Finance Laws on Private Funding of Political Parties", Australian Journal of Public Administration (2018, doi:10.1111/1467-8500.123.19); Jennifer Rayner, "More Regulated, More Level? Assessing the Impact of Spending and Donation Caps on Australian State Elections", in Anika Gauja and Marian Sawer, eds, Party Rules? Dilemmas of Political Party Regulation in Australia (Acton, 2016).
} 
can improve the quality of politics, and the "pessimists" who doubt such claims.9 Secondly, to enable our assessment of the New South Wales reforms, we propose an evaluative framework that draws on research on the "quality of democracy" ${ }^{10}$ These studies evaluate democratic systems, but say little about political finance regulation.

The remainder of the article is organized into four sections. In the first, we review the relevant literature on political finance, and note that research on the consequences of regulation has focused mainly on citizens. While perhaps understandable, this concentration has meant that the matter of how political finance regulation affects donors remains poorly understood. In the second section, we present a framework for assessing this relationship. The third section presents the background for our empirical examination: firstly by summarising the reforms that took place in New South Wales between 2008 and 2015; and then by discussing the official data that we analyse. The fourth section presents our findings and interprets them in terms of the evaluative framework. We observe, consistent with the views of the regulatory optimists, that the new, enhanced regulations have probably made political financing fairer, and thus improved the quality of democracy, in New South Wales. The conclusion reviews our empirical analysis and highlights its connections to broader literatures.

\section{Political Finance Regulation and Its Impact on Donors}

There is a large, interdisciplinary literature on political finance regulation. Much of it focuses on the United States, where the financing of politics has been a highly topical issue since at least the $1970 \mathrm{~s} .{ }^{11}$ But there are also significant studies of political finance regulation in other countries, including Australia. ${ }^{12}$ Despite the knowledge that such work has generated, a key limitation is its lack of attention to the relationship between political finance regulation and donor behaviour, and how this connects to normative goals. This is the problem we engage in the subsequent sections of this article.

Often, it is assumed that with appropriate sanctions in place, donors will simply follow the rules, thereby ensuring that regulation has its intended effects. This view underlies "optimistic" arguments for tighter rules. But critics point out that this expectation may be somewhat naïve. After all, governing parties have weak incentives to reform unfair and opaque financing rules if they benefit from them. Moreover, even if regulations are tightened, there is little chance that anything important will change, argue Samuel Issacharoff and Pamela S. Karlan, because of the intrinsic difficulty of regulating money in politics - like water in a natural ecosystem, "[t]he money that reform squeezes out of the formal campaign process must go somewhere". ${ }^{13}$

These contrasting viewpoints are rarely tested with appropriate evidence. But while the literature on political finance devotes little attention to the question of how

\footnotetext{
${ }^{9}$ See, for instance, Samuel Issacharoff and Pamela S. Karlan, "The Hydraulics of Campaign Finance Reform”, Texas Law Review, Vol. 77 (1998), pp.1705-1738; Daniel Hays Lowenstein, “On Campaign Finance Reform: The Root of All Evil is Deeply Rooted", Hofstra Law Review, Vol. 18, 2 (1989), pp.301-367; Bradley A. Smith, "Faulty Assumptions and Undemocratic Consequences of Campaign Finance Reform", Yale Law Journal, Vol. 105 (1996), pp.1049-1091.

${ }^{10}$ See, for instance, Arend Lijphart, Patterns of Democracy: Government Forms and Performance in Thirty-Six Countries (New Haven, 1999), pp.275-300; Guillermo O’Donnell, Jorge Vargas Cullell and Osvaldo M. Iazzetta, eds., The Quality of Democracy: Theory and Applications (Notre Dame, 2004); Leonardo Morlino, "What is a 'Good' Democracy?", Democratization, Vol. 11, 5 (2004), pp.10-32. Note, however, the valuable frameworks established by various practitioner bodies, including International IDEA, discussed below, p.9.

${ }^{11}$ See, for instance, Abrams and Settle, "The Economic Theory of Regulation and Public Financing of Presidential Elections"; La Raja, Small Change; Primo and Milyo, "Campaign Finance Law and Political Efficacy".

${ }^{12}$ For a review, see Tham, Money and Politics.

${ }^{13}$ Issacharoff and Karlan, "The Hydraulics of Campaign Finance Reform”, p.1713.
} 
regulations impact on donors, it does examine other issues that inform our analysis of this problem. Studies in one research agenda compare regulations across nations or over time, which helps to clarify what options were available to the New South Wales reformers. ${ }^{14}$ In another line of inquiry, studies attempt to explain the occurrence (and absence) of political finance reforms, which informs our understanding of the drivers of the New South Wales reforms. ${ }^{15}$

A third research agenda examines the effects of regulation, but with a focus on citizens rather than donors. ${ }^{16}$ These studies analyse how regulations impact on citizens' trust in politicians and institutions and their propensity to vote, since "political trust" is a reliable predictor of "electoral turnout". But such studies fail to tell us much about the effectiveness of regulation and its capacity to restrain donors. On such matters, citizens' attitudes can be no more than a noisy indicator because there may be a significant gap between how they view the financing system and how that system is actually operating. ${ }^{17}$

Instead, it is better to examine how regulation has affected the pattern of donations and thus the behaviour of donors; this is the approach we adopt. It assumes, of course, that the data we analyse accurately capture the scale of donations. A serious issue here is the fact that we can only analyse what has been disclosed, so any observations we make will be more challengeable if a large portion of political finance transactions take place below the disclosure threshold (or above it, but without being reported). While there is certainly room for greater transparency in this area, and some recent work draws attention to this problem, ${ }^{18}$ we retain a basic confidence in the quality of official data (in Australia) because it is supported by legally-enforced reporting requirements in a country with competent electoral administration authorities and a low corruption culture.

\section{Evaluating Political Finance Regulation}

So, how do we evaluate the effects of political finance regulation? While regulation can have subtle effects, it makes practical sense to assess it with indicators that are easily observable. Furthermore, the indicators should capture important democratic principles. A challenge in this regard is the absence of consensus on ideals and, therefore, the goals that regulation ought to prioritize. An important disagreement

\footnotetext{
${ }^{14}$ See, for instance, Pinto-Duchinsky, "Financing Politics"; Ewing and Issacharoff, Party Funding and Campaign Financing in International Perspective; Norris and Van Es, Checkbook Elections?.

${ }^{15}$ See, for instance, Richard Katz and Peter Mair, "Changing Models of Party Organization and Party Democracy: The Emergence of the Cartel Party", Party Politics, Vol. 1, 1 (1995), pp.525-534; Zim Nwokora, "The Distinctive Politics of Campaign Finance Reform", Party Politics, Vol. 20, 6 (2014), pp.918-929; Susan E. Scarrow, "Explaining Political Finance Reforms: Competition and Context", Party Politics, Vol. 10, 6 (2004), pp.619-639.

${ }^{16}$ See, for instance, John J. Coleman and Paul F. Manna, "Congressional Campaign Spending and the Quality of Democracy”, The Journal of Politics, Vol. 62, 3 (2000), pp.757-789; Primo and Milyo, "Campaign Finance Law and Political Efficacy".

${ }^{17}$ See Necmi K. Avkiran, Direnç K. Kanol and Barry Oliver, "Knowledge of Campaign Finance Regulation Reduces Perceptions of Corruption", Accounting and Finance, Vol. 56, 4 (2016), pp.961984

${ }^{18}$ See Lindy Edwards, "Political Donations in Australia: What the Australian Electoral Commission Disclosures Reveal and What They Don't", Australian Journal of Public Administration (2018, doi.org/10.1111/1467-8500.12283). Beyond the issue of donations falling below the disclosure threshold and therefore being undeclared, the primary shortcomings of the current regimes that Edwards observed referred to the identity of donors and establishing their links to the parties, rather than the proportion of donations above the reportable amount that were disclosed.
} 
concerns the priority that should be given to "equality" (or "fairness") and "liberty" when these goals clash. ${ }^{19}$ Those who prioritise equality will prefer different regulations from those who prioritise liberty.

A solution to this problem, which follows the literature on the quality of democracy, is to impose priorities. ${ }^{20}$ As Leonardo Morlino argues, "analysis of the quality of democracy $[\ldots]$ requires not only that we assume some definition of democracy, but also that we establish a clear notion of its quality". ${ }^{21}$ In so doing, the assessment operationalises a particular view of an "ideal" or "good" democracy. It applies criteria that are consistent with that view, but which may not be useful measures of an alternative conception. Nonetheless, we think this is the best way to evaluate the practical workings of a set of political finance regulations because the alternative namely, assessing their quality in multiple, competing directions - can lead to ambiguous conclusions when regulatory setups are compared. This would be a problem because an evaluation should help to clarify, rather than obscure, such matters.

Moreover, among democratic theorists and experts on political finance, there is much agreement at a broad level about what ought to be the objectives of political finance regulation, with most scholars supporting the view that it should promote fairness, by helping to equalise the capacity of citizens to participate in politics and influence the direction of public policies. For example, Robert A. Dahl explains that a citizen's "effective participation" - that is, the "opportunities for making known to others members [of the political community] their views about what the policy should be" - is a basic requirement of an ideal democracy, in part because it enables the democratic system to also perform effectively in other respects. ${ }^{22}$ There is probably less consensus on such matters among political practitioners. Yet it seems reasonable to say that in most established democracies the principle of equality dominates, ahead of liberty, in the political and legal discourse on political finance. ${ }^{23}$ The United States is perhaps an exception. ${ }^{24}$

In countries where the capacity of state authorities to enforce the rules that exist is a major concern, boosting enforcement capacity is often regarded as the most pressing priority, and perhaps even more important than ensuring that the rules promote fairness. ${ }^{25}$ But in Australia and in many other established democracies, electoral

\footnotetext{
19 See, for instance, Ronald Dworkin, Sovereign Virtue: The Theory and Practice of Equality (Cambridge, 2000); Anika Gauja, "The Legal Regulation of Political Parties: Is there a Global Normative Standard?", Election Law Journal: Rules, Politics and Policy, Vol. 15, 1 (2016), pp.4-19; J. Tobin Grant and Thomas Rudolph, Expression vs. Equality: The Politics of Campaign Finance Reform (Columbus, 2004).

${ }^{20}$ See, for instance, O'Donnell, Cullell and Iazzetta, The Quality of Democracy; Lijphart, Patterns of Democracy, pp.275-300. An advantage of deriving criteria from the scholarship, rather than the expressed aims of lawmakers, is that the framework can more easily avoid the charge that it is inherently partisan.

${ }^{21}$ Morlino, "What is a 'Good' Democracy?", p.10.

22 Robert A. Dahl, On Political Equality (New Haven, CT, 2006), p.9; See also, Pippa Norris, Building Political Parties: Reforming Legal Regulations and Internal Rules (Stockholm, 2004); Anika Gauja and Marian Sawer, "Party Rules: The Regulatory Gap", in Gauja and Sawer, eds, Party Rules?; Tham, Money and Politics.

${ }^{23}$ See Gauja, "The Legal Regulation of Political Parties", pp.4-19. There is a general consensus, in international norms of regulation, that states may legitimately regulate donations to political parties, as well as parties' expenditure, with the aim of encouraging a level playing field and minimizing the risk of corruption through private finance, p.11.

${ }^{24}$ See Anika Gauja, Political Parties and Elections: Legislating for Representative Democracy (Farnham, 2010), pp.179-187.

${ }^{25}$ See Elin Falguera, Samuel Jones and Magnus Ohman, eds, Funding of Political Parties and Election Campaigns: A Handbook on Political Finance (Stockholm, 2013).
} 
authorities are well-resourced and widely regarded as being competent and impartial, so the enforcement problem is much less of an issue.

Thus, the criteria we outline below for assessing political finance regulation focus on the normative goal of equality and, more precisely, assume that regulation should aim to enable citizens, whatever their income, wealth or preferences, to participate equally in politics. Our emphasis on this goal is consistent with guidelines issued by domestic and international watchdogs, most notably the Democratic Audit of Australia, the European Commission for Democracy through Law (Venice Commission) and International IDEA; and benchmarks in the quality of democracy literature. In Morlino's framework, for instance, "progressive implementation of greater political, social and economic equality" is an indicator of a democracy's quality in "substantive" terms. ${ }^{26}$

\section{Evaluating the Fairness of Political Donations}

While following the broad direction suggested in the scholarship and in established guidelines, we propose more fine-grained criteria that enable a detailed evaluation of a set of political finance regulations, and in particular their impact on donors. The criteria aim to capture the fairness, and thus democratic "quality", of a pattern of donations by assessing: the unit size of donations; their source; the sum of donations received; and the distribution of funds among recipients. We flesh out these criteria below, drawing on research on political finance and the quality of democracy. Consistent with the arguments above, the criteria we propose are easily observable using data from official sources; and capture normatively significant patterns of behaviour, relating to equality of political participation and influence. This simple framework can be used to compare systems of regulation across multiple jurisdictions. Furthermore, it can be used to assess reforms within a single jurisdiction, as we show in our assessment of the preand post-reform setups in New South Wales.

1. Unit size of donations. There is a widespread belief that small donations are more beneficial to democracy, or at least pose fewer risks, than large donations. ${ }^{27}$ So, to enhance the quality of democracy, political finance regulation should encourage more small donations relative to large ones. The issue here is not the total amount of money that a party receives (though this is also an issue, as we discuss below), but the size of the units that make up that total. From this standpoint, then, it is better for a party to receive $\$ 1$ from 1,000 people than $\$ 1,000$ from one person, even though the party raises the same amount of money in both scenarios. This argument is based on the suspicion that parties are highly sensitive to the interests of their big donors. Thus, these "fat cats" may exert an outsized influence on the party's policies, resulting in the diminished influence of smaller donors. Since there are likely to be many more "small" donors than "large" ones, this arrangement leads to an unequal distribution of influence among the party's financial backers.

Furthermore, given that big donors are able to donate sums that are unavailable to the ordinary citizens who do not donate to a party, the policies they prefer and advocate for may drive the party's decision-making away from the "public interest", where this is understood to be the needs and preferences of most citizens (or the typical citizen). The risk of such divergence is much lower when a party's revenue comes mainly from small donors since, compared to fat cats, they are likely to have levels of income and

\footnotetext{
${ }^{26}$ Morlino, "What is a 'Good' Democracy?”, p.13.

${ }^{27}$ Fred Wertheimer and Susan Weiss Manes, "Campaign Finance Reform: A Key to Restoring the Health of Our Democracy", Columbia Law Review, Vol. 94 (1994), pp.1126-1159; Bruno Wilhelm Speck, "Money in Politics: South Political Competition and Trust in Government", Background Paper, OECD Policy Forum on "Restoring Trust in Government: Addressing Risks of Influence in Public Decision Making”, OECD, Paris, 14-15 November 2013.
} 
wealth that are closer to the average in the society. Therefore, we might expect their policy preferences to align more closely with those of ordinary citizens who do not donate to a party.

2. Source of donations. A second dimension for assessing political finance regulation concerns who is permitted to donate. A key debate in this regard concerns the status of corporate entities and, specifically, whether they should be treated as being equivalent to citizens. This question arises because the citizens in a democracy are a privileged class, with rights, including the right to make political donations, that may not be extended to non-citizen entities. ${ }^{28}$ On the other hand, corporate entities are treated as legal persons for many other purposes and their contributions may be needed to adequately fund elections campaigns.

A common solution to this dilemma, and the one that applies in New South Wales, ${ }^{29}$ is to permit donations from corporations, in general, while restricting donations from particular corporate entities. Businesses that stand to gain immediately and significantly from government policy changes - for example, in licensing and planning applications - have a strong incentive to pressure the government (and parties that may form the government in the near future).$^{30}$ Therefore, donations from such sources are risky from a normative standpoint because they are more likely (than money from other sources) to facilitate corruption, or the perception thereof. In Australia, this argument has been invoked in debates about donations from the gambling, liquor and tobacco industries; property developers; and from persons and entities that reside beyond the jurisdiction (especially overseas).

3. Total value of donations. The unit size and source of donations pertain to the structure of donations to a party, and not the total amount that the parties, as a whole, receive. Thus, using only the criteria above, a party might raise a very large sum of money without this raising normative concerns. This would be the case if the money was raised in small units, from "safe" sources. In practice, however, there seems to be a division between countries and cultures where this situation (i.e., a party raising large sums from safe sources) is not viewed as a problem, and other countries and cultures where it is.

The United States, particularly in recent years, is the prime example of the first case: candidates and parties raise increasingly large amounts of money, and there seems to be little appetite to end this arms race. Indeed, Barack Obama campaigned for political finance reform in his 2008 presidential election campaign, but later became the first candidate ever to opt out of the federal public financing system and the spending limits associated with it, seemingly without penalty. Australia appears to be firmly in the second category: a country where the sum total of donations and spending is regarded as a cause for concern. ${ }^{31}$ The evidence on this point suggests that ordinary Australians, but also the political elite, worry about the cost of campaigns, which suggests that the sum total of donations should be used to assess regulations; and the normatively preferable outcome would be a lower (or reduced) total. ${ }^{32}$

\footnotetext{
${ }^{28}$ See, for instance, Joo-Cheong Tham, "Of Aliens, Money and Politics: Should Foreign Political Donations Be Banned?”, King's Law Journal, Vol. 28, 2 (2017), pp.262-278.

29 The Queensland government has promised to introduce a ban on donations from property developers. See, for instance, Felicity Caldwell, "Laws to Ban Property Developer Donations to be Reintroduced Within Six Months", Brisbane Times, 25 January 2018.

${ }^{30}$ See, for instance, McMenamin, If Money Talks, What does it Say?, p.73.

${ }^{31}$ See, for instance, Anderson and Tham, "Dynamics of Electoral Expenditure and the 'Arms Race' Thesis".

${ }^{32}$ This preference might reflect the fear that a large total is more likely (than a small total) to reflect the disproportionate influence of fat cats.
} 
4. Distribution of funds among political parties. Research on political finance raises the concern that a governing party might take advantage of its incumbency by crafting laws to improve its chances of staying in power. ${ }^{33}$ In a properly functioning democracy, there are serious constraints on the governing party's capacity and willingness to act in this way. Perhaps the most significant is the fact that it always faces the risk of electoral defeat, which means that it can only ever have a temporary hold on any incumbent-favouring regulations; and when it loses these regulations would obstruct its return to power. ${ }^{34}$ This logic suggests that democratic governments will tend not to design regulations that are overtly advantageous to the incumbent party.

Crucially, this does not mean that donations will flow evenly or proportionately to the parties in a party system. In fact, there are reasons to expect the flow of donations to favor large parties, especially when they are seen as pro-business ${ }^{35}$ and this could undermine the competitiveness of elections and thereby the quality of democracy. One reason is suggested by the cartelization thesis, which points out that while it is likely to be counterproductive for a governing party to craft regulations in its favour, such a strategy may be rational for the group of "insider" parties who take turns in power. Thus these parties may cooperate to create and maintain regulations that enable them to raise more money than the smaller parties.

But cartelization is not necessary to ground the expectation that donors will tend to favor the major parties. If donors are "rational", and seek to maximize the "return" on their "investment", it makes sense for them to donate more to the major parties who dominate policy-making. ${ }^{36}$ The competitive chances of the minor parties will be diminished as a consequence, which reduces the influence of their supporters. The normatively desirable goal, in this case, is a set of regulations that encourages a flow of funds to parties in a manner that is roughly proportional to their size.

Drawing together these criteria, we can specify patterns of giving that are congruent with: (a) a high quality of democracy and (b) a low quality of democracy. The first, high-quality pattern arises when the bulk of donations are small in size; they come from various sources but not entities with a potential conflict of interest; they sum to give a reasonably small total; and are distributed proportionately across parties. Whereas a pattern of donations with the opposite characteristics - a concentration of large donors, including from dubious sources; a large total; and a skewing of funds to the major parties - will tend to undermine the quality of democracy. A mix of these characteristics - for example, if donations are typically small in size but flow only to the major parties - indicates a pattern of donations of intermediate quality.

\section{The Regulation of Political Finance in New South Wales}

We use this framework to evaluate the reforms to political finance regulation in NSW since 2008. If the reforms have produced a higher quality pattern of donations than before, we can conclude they have succeeded, or were effective, in normative terms. Conversely, if the reforms resulted in a lower quality pattern of donation, we can conclude they were largely ineffective. We assess these regulations using the criteria of our framework, but it should be noted that the framework's inclination - and specifically its emphasis on improving equality of participation and influence -

\footnotetext{
${ }^{33}$ See, for instance, Kenneth F. Greene, "Party Finance and Single-Party Dominance in Mexico and Beyond," in Anthony Butler, ed., Paying for Politics: Party Funding and Political Change in South Africa and the Global South (Auckland Park, 2010), pp.20-52.

${ }^{34}$ See Nwokora, "The Distinctive Politics of Campaign Finance Reform".

${ }^{35}$ See McMenamim, If Money Talks, What Does it Say?

${ }^{36}$ Indeed, they may donate to all the major parties to hedge their bets. See Tham, Money and Politics; McMenamin, If Money Talks, What Does It Say?
} 
echoes the arguments that were advanced by the sponsors of reform. For instance, one of the key reform initiatives, the Election Funding and Disclosures Amendment Act 2010 (New South Wales), was justified by its sponsors, the Labor government led by Kristina Keneally, as an attempt to reduce "the advantages of money in dominating political debate [and] provide for a more level playing field for candidates seeking election, as well as for third parties who wish to participate in political debate". ${ }^{37}$

Although the modern regulation of political finance in New South Wales can be traced back to 1981, with the introduction of the Election Funding Act of that year, we limit our analysis to the years since 1998/1999 because it is only during this period that data on donations has been systematically collected by official agencies. Despite this time restriction, the period covered still encompasses important reforms, especially in the years since 2008 when the system of enhanced regulations has been introduced. Before 2008, the state operated with limited regulations, consisting of public funding and disclosure provisions. This regulatory framework has been significantly tightened since 2008, though, with the introduction of caps and bans on donations and expenditure, and revisions of public funding and disclosure provisions. These regulatory changes were brought about through four pieces of legislation, which are summarized in Table 1 below.

Table 1: Changes to the Regulation of Political Finance in New South Wales (2008-2015)

\begin{tabular}{|c|c|}
\hline Legislation & Key Elements \\
\hline $\begin{array}{l}\text { Election Funding Amendment } \\
\text { (Political Donations and } \\
\text { Expenditure) Act } 2008 \text { (NSW) }\end{array}$ & $\begin{array}{l}\text { - Introduced biannual disclosure obligations. } \\
\text { - Banned anonymous donations and loans made } \\
\text { during relevant six-month periods. }\end{array}$ \\
\hline $\begin{array}{l}\text { Election Funding and } \\
\text { Disclosures Amendment } \\
\text { (Property Developers } \\
\text { Prohibition) Act } 2009 \text { (NSW) }\end{array}$ & - Banned donations from 'property developers' \\
\hline $\begin{array}{l}\text { Election } \quad \text { Funding and } \\
\text { Disclosures } \\
\text { Amendment Act } 2010\end{array}$ & $\begin{array}{l}\text { - Caps on donations and electoral } \\
\text { communication expenditure. } \\
\text { - Public funding scheme altered, with Central } \\
\text { Fund, Constituency Fund and Political } \\
\text { Education Fund abolished and replaced by: } \\
\text { (a) Election Campaigns Fund, with payments } \\
\text { based on reimbursement sliding scale tied to } \\
\text { caps on electoral communication expenditure; } \\
\text { (b) Administration Fund, with payments based } \\
\text { on a flat rate per number of elected members; }\end{array}$ \\
\hline
\end{tabular}

${ }^{37}$ Kristina Keneally, Premier, New South Wales Parliamentary Debates, Legislative Assembly, 28 October 2010, p.27168. 


\begin{tabular}{|l|l|}
\hline & $\begin{array}{l}\text { (c) Policy Development Fund, which is similar } \\
\text { to Political Education Fund, with payments } \\
\text { based on number of first preference votes. } \\
\text { - Extension of ban on donations from property } \\
\text { developers and their close associates to } \\
\text { gambling, liquor and tobacco companies (and } \\
\text { their close associates). } \\
\text { - Biannual disclosure system changed to annual } \\
\text { disclosure system. }\end{array}$ \\
\hline $\begin{array}{l}\text { Election Funding, Expenditure } \\
\text { and Disclosures Amendment Act } \text { AsW) }\end{array}$ & $\begin{array}{l}\text { - Donations restricted to those on electoral rolls, } \\
\text { hence bans on donations from individuals not on } \\
\text { electoral rolls, corporate entities and trade } \\
\text { unions (including membership fees paid by trade } \\
\text { unions affiliated to the NSW ALP). } \\
\text { - Spending of affiliated organisations aggregated } \\
\text { to caps of their respective political parties (e.g. } \\
\text { spending of trade unions affiliated to NSW ALP } \\
\text { aggregated to the caps applying to NSW ALP). }\end{array}$ \\
\hline
\end{tabular}

We examine whether and how these reforms have affected the pattern of donations in the state and, via this mechanism, its quality of democracy. To investigate these questions, we analyse donations to the state's political parties, as reported to the Australian Electoral Commission (AEC) and New South Wales Electoral Commission (NSWEC), from financial year 1998/99 to 2015/16. Since 1998/99, parties have had to declare, annually, to the AEC all donations they receive in excess of a mandated threshold, which is adjusted to take account of inflation; that threshold was $\$ 13,000$ in 2015/16. Putting this another way, the AEC data track donations that are not "modest" or "small", a practice that suggests its adherence to the view, which the framework of the previous section elaborates, that large donations are more problematic than small ones and therefore need to be scrutinised more closely.

Alongside these party-reported donations receipts, the AEC also requires donors to submit details of their contributions. ${ }^{38}$ If the information reported by parties and donors were complete and accurate, there would be no discrepancies between party- and donor-reported data. In fact, as we report below, there are discrepancies and this is relevant for assessing the regulations. In addition to the AEC-generated data, New South Wales legislation requires donors and parties to submit details of their transactions. However, the dataset supplied to us from the NSWEC contained only the party-supplied returns, which, though not ideal, was not a significant inconvenience since party-reported data tends to be more reliable than donor-reported data. The NSWEC disclosure threshold was $\$ 1,000$ in 2014/15, much lower than that applied by the AEC. As a result, this dataset enables a finer-grained analysis of donations. But, the NSWEC data series only begins in 2004/05 and thus covers a narrower timespan than the AEC data.

To summarize, we analyse AEC donations data as reported by parties and donors; and NSWEC donations data as reported by parties. Drawing on these sources we compare the pattern of donations before and after the point of transition (i.e., mid2008) from relatively loose regulations to the system of enhanced regulation, focusing on the consequences of reform for the quality of democracy in the state as theorised in our evaluative framework.

\footnotetext{
${ }^{38}$ Donors are not required to submit details of donations below the disclosure threshold, but often do so in practice.
} 
We can directly observe change in the value of donations (i.e., the sum of all donations in a given year); and change in the number of donations (i.e., the sum of all transactions in a year). The first observation can be used to assess the pattern of money flows against the third criterion of our framework, relating to the aggregate total of donations, where we posited that smaller totals are associated with higher quality democracy. Intuitively, we might expect that the number of donations will be closely related to the value of donations; but this will not be the case if the size of the typical donation has changed. The value and number of donations can be used to calculate the average donation size, which can be used to assess the first plank of our framework, namely the suggestion that "small" donations are more conducive to high-quality democracy than "large" donations.

The official data can also be used to assess the second plank of the framework; and more specifically, the risk of breach to prohibitions of certain classes of donations. The reforms outlawed donations from property developers and gambling, alcohol and tobacco interests. While it is not possible to directly observe the extent of illegal donations, we can track donations from sectors that have close industry connections to the prohibited ones. We describe these as "potentially suspicious sources". The fourth plank of our framework highlighted the problem with an uneven (i.e., disproportionate) distribution of resources across parties; to assess this dimension, we calculated the flow of donations to the different parties in the state.

\section{Results: Donations and Democracy in New South Wales}

In this section, we discuss the results from our empirical analysis of the pattern of donations prior to and since the introduction of enhanced regulations in New South Wales. This analysis applies simple techniques: we compute various totals and map the change in those totals over time. The most distinctive contribution of this analysis, therefore, is its grounding in an evaluative framework that links observations about donations to the quality of democracy.

Total Value and Unit Size of Donations. We argued, in the elaboration of our evaluative framework, that there is a relationship between the total value of donations and the typical unit size of donations (i.e., planks 3 and 1), on the one hand, and the quality of democracy, on the other. Specifically, a smaller total and a smaller unit size indicate a higher quality pattern of donations. Based on this argument, the political finance reforms in New South Wales should be viewed as a success if the total value of donations has been lower in the post-reform environment than it was prior to these reforms, and the size of the typical donation has also decreased. ${ }^{39}$

Our analysis of the official data shows that since the introduction of the new regulations, there has been a general decrease in the total value of donations in New South Wales. ${ }^{40}$ This point is shown in Figure 1 below, which displays the total value of donations reported to the AEC by political parties in New South Wales between the 1998/99 and 2015/16 financial years. ${ }^{41}$ The raft of legislation, introduced from mid2008 onward, is also indicated. Despite fluctuations, there is clearly a downward trend over time, which has accelerated since 2008. Prior to 2008, the total value of donations exceeded $\$ 10$ million in most years; and the years when this wasn't the case were exceptional. This pattern has been reversed in the post-reform years: crossing the $\$ 10$ million threshold is now the exception and no longer the norm. Indeed, only in two

\footnotetext{
${ }^{39}$ As noted earlier, the implications of a change in the number of transactions is ambiguous: it depends on how other aspects of the donation flow have changed.

${ }^{40}$ For an analysis of the effects of the individual pieces of legislation, see Anderson et al., "Less Money, Fewer Donations".

${ }^{41}$ To control for the effects of inflation, we express all financial details in 2015/16 dollar amounts.
} 
years did the total exceed this figure. A similar trend is also observed in the value of donations reported by donors (not shown), and the downward trajectory is even more pronounced. Thus, the evidence strongly suggests that donors are now giving less than before, which, from a normative standpoint, is a welcome development. But these results also suggest, more worryingly, that donors are underreporting their contributions to a greater extent than before.

Figure 1: Total Value of Donations (Reported by Parties to AEC, Above Threshold)

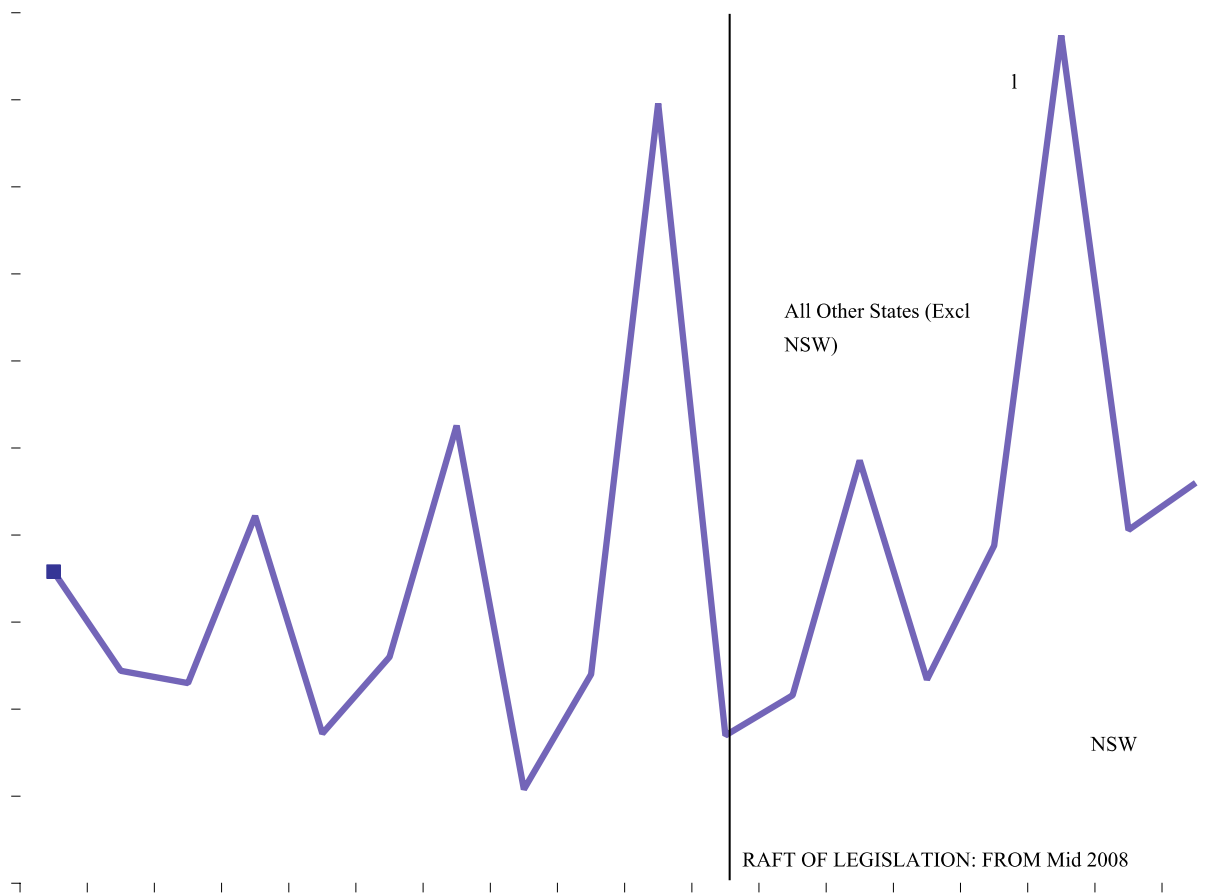

Table 2 below presents a "before" and "after" snapshot of the total value of donations (in a financial year), as reported by parties to the AEC. The table confirms the trend 
suggested in the preceding chart. Since 2008, the total value of donations per year has decreased by over 40 per cent, from above $\$ 15.5$ million in the pre-reform period to $\$ 8.8$ million during the post-reform years. A downward trend can also be observed in several other jurisdictions during this time, but the tightening has been greatest in New South Wales. Given that the New South Wales reforms have been more sweeping than those in other jurisdictions, this observation supports the conjecture that regulations matter, and that tighter regulations have greater effects on the behaviour of donors. Observations from the other states are also consistent with this conjecture: in states such as South Australia and Victoria, where reforms resembling New South Wales's have been introduced, there has been a decline in the average value of donations; whereas in Queensland, where regulations have been relaxed, the value of donations has increased. ${ }^{42}$

Table 2: Total Value of Donations per Financial Year across Jurisdictions (Reported by Parties to AEC)

\begin{tabular}{|l|c|c|c|}
\hline Jurisdiction & Pre-Reform Years & Post-Reform Years & Change (\%) \\
\hline Federal & $17,292,621$ & $20,846,504$ & 20.6 \\
\hline $\begin{array}{l}\text { Australian Capital } \\
\text { Territory }\end{array}$ & 889,561 & 957,404 & 7.6 \\
\hline New South Wales & $15,552,877$ & $8,753,717$ & -43.7 \\
\hline Victoria & $10,179,669$ & $9,651,494$ & -5.2 \\
\hline Queensland & $8,822,487$ & $10,177,637$ & 15.4 \\
\hline South Australia & $2,012,822$ & $1,600,231$ & -20.5 \\
\hline Western Australia & $2,623,741$ & $3,183,102$ & 21.3 \\
\hline Tasmania & 363,794 & 903,406 & 148.3 \\
\hline Northern Territory & 452,345 & 572,052 & 26.5 \\
\hline All Australia & $58,189,917$ & $56,813,005$ & -2.4 \\
\hline
\end{tabular}

While the total value of donations in New South Wales has declined, there has not been a marked change in the size of the typical donation between the pre- and post-reform periods. Figure 2 below shows the mean value of donations per week since the 1998/99 financial year, as reported to the Australian Electoral Commission by the New South Wales parties. To facilitate comparison, this time series is presented alongside equivalent data from other jurisdictions, specifically the mean value of donations to the federal parties and the mean value of donations to the parties in the other states (combined). The figure shows there has been a generally upward trend in the value of federal donations and also in the other states. In New South Wales, the pattern is less clear and might be described as trendless fluctuation. The year-to-year figures vary with the electoral cycle, as we might expect, but there is no evidence from this data to suggest that the reforms have affected the unit size of donations.

\footnotetext{
${ }^{42}$ Prior to the relaxation of regulations in Queensland in 2012, donations to, and spending by, the major parties was on a downward trajectory; see Rayner, "More Regulated, More Level?".
} 
Figure 2: Mean Value of Donations (Reported by Parties to AEC, Above Threshold)

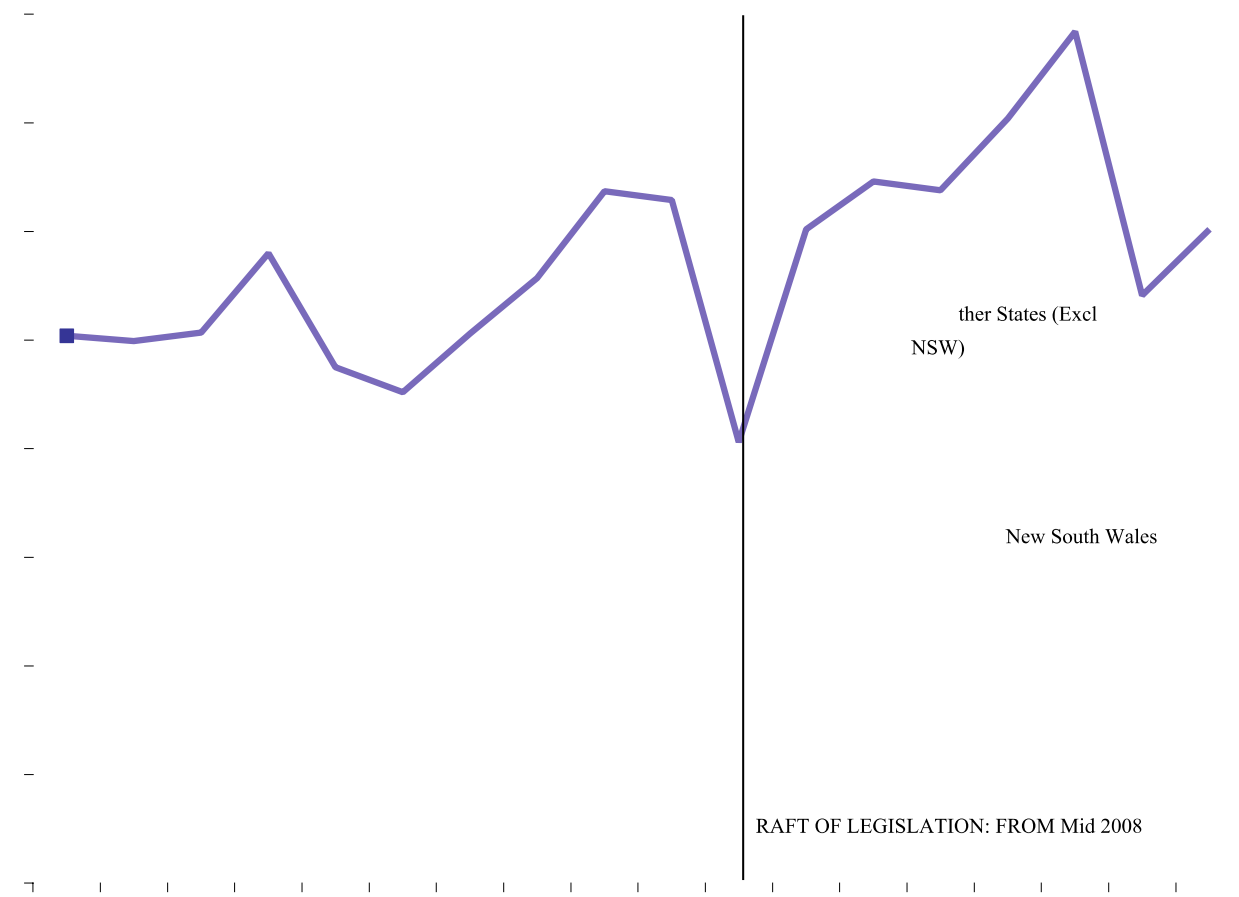

This point is supported by the data summarized in Table 3 below, which shows the "before" and "after" snapshot for the mean size of donations, as reported by donors to the AEC. In New South Wales, the mean donation actually increased in size, on average by 17 per cent. Admittedly, this was a smaller increase than observed in any other jurisdiction. But it still counts as evidence that, in terms of the unit size criterion (plank 1 of the framework), the pattern of donations appears to be undercutting the quality of democracy in the state. 
Table 3: Mean Donation Size across Jurisdictions (Reported by Parties to AEC, Above Threshold)

\begin{tabular}{|l|c|c|c|}
\hline Jurisdiction & Pre-Reform Years & Post-Reform Years & Change (\%) \\
\hline Federal & 53,415 & 63,184 & 18.3 \\
\hline Australian Capital Territory & 84,718 & 68,888 & -18.7 \\
\hline New South Wales & 33,666 & 39,530 & 17.4 \\
\hline Victoria & 48,658 & 67,554 & 38.8 \\
\hline Queensland & 45,573 & 45,578 & 0.0 \\
\hline South Australia & 43,384 & 60,717 & 40.0 \\
\hline Western Australia & 35,961 & 36,445 & 1.3 \\
\hline Tasmania & 33,756 & 44,916 & 33.1 \\
\hline Northern Territory & 26,849 & 32,311 & 20.3 \\
\hline All Australia & 41,977 & 50,756 & 20.9 \\
\hline
\end{tabular}

This conclusion is based on findings from party-reported data to the AEC. But as noted earlier, the AEC applies a relatively high compulsory disclosure threshold of around $\$ 13,000$, so it makes sense to be cautious in drawing conclusions about the size of the typical donation based on analysis of these data. However, donors often voluntarily disclose all donations, including those below threshold, which we can analyse. And New South Wales's lower reportable thresholds can also help to remedy this problem. A second concern is the significant variation in donation size, especially the skew caused by the small number of extremely large donations. To address this problem, we calculated a "trimmed mean" using the central 95 per cent of observations from the AEC donor-reported data and NSWEC party-reported data, having eliminated the top and bottom 2.5 per cent of donations in terms of value.

Tracking this trimmed mean over time, for both the AEC and NSWEC datasets, we observe patterns that are quite different from those previously described. Table 4 below summarizes the trimmed AEC data. As that table shows, these data now suggest that the size of average donation has decreased. During the pre-reform years, the average donation within this sample was approximately $\$ 6,300$, which is $\$ 1,000$ more than the average donation in the post-reform period. This trend holds during election and nonelection years.

\section{Table 4: Mean Donation Size in NSW (Reported by Donors to AEC, Trimmed Mean)}

\begin{tabular}{|l|c|c|c|c|}
\hline & $\begin{array}{c}\text { Pre-Reform } \\
\text { Years }\end{array}$ & $\begin{array}{c}\text { Post-Reform } \\
\text { Years }\end{array}$ & Change (\%) & $\begin{array}{c}\text { Change } \\
\mathbf{( \$ )}\end{array}$ \\
\hline Mean Size & 6,377 & 5,307 & -16.8 & $-1,070$ \\
\hline $\begin{array}{l}\text { Mean Size for } \\
\text { Election Periods }\end{array}$ & 6,293 & 5,076 & -19.3 & $-1,217$ \\
\hline $\begin{array}{l}\text { Mean Size for Non- } \\
\text { Election Periods }\end{array}$ & 6,430 & 5,404 & -16.0 & $-1,026$ \\
\hline
\end{tabular}

This trimmed, AEC data relating to New South Wales are presented as a time series in Figure 3 below. To enable comparison, the figure also shows the trimmed mean for the other jurisdictions based on the AEC data, and the trimmed mean calculated from the NSWEC sample. The NSWEC data confirm the downward trend that is apparent from the AEC data; in fact, they suggest there has been a sharper drop-off in the size of the typical donation than does the AEC data. Comparing New South Wales to the other jurisdictions, it appears the downward trend in this state is unusual. At the federal level and in the other states, treated together, there has been fluctuation over time (especially at the federal level), but no evidence of a clearly downward trajectory. Overall, these 
observations relating to unit size suggest a mixed conclusion: the size of the average donation has gone up since the reforms; but the variation has become more skewed such that if we limit our focus to central tendencies, a downward trend can be observed. ${ }^{43}$

Figure 3: Mean Value of Donations (Reported by Donors to AEC and by Parties to NSWEC, Trimmed Mean)

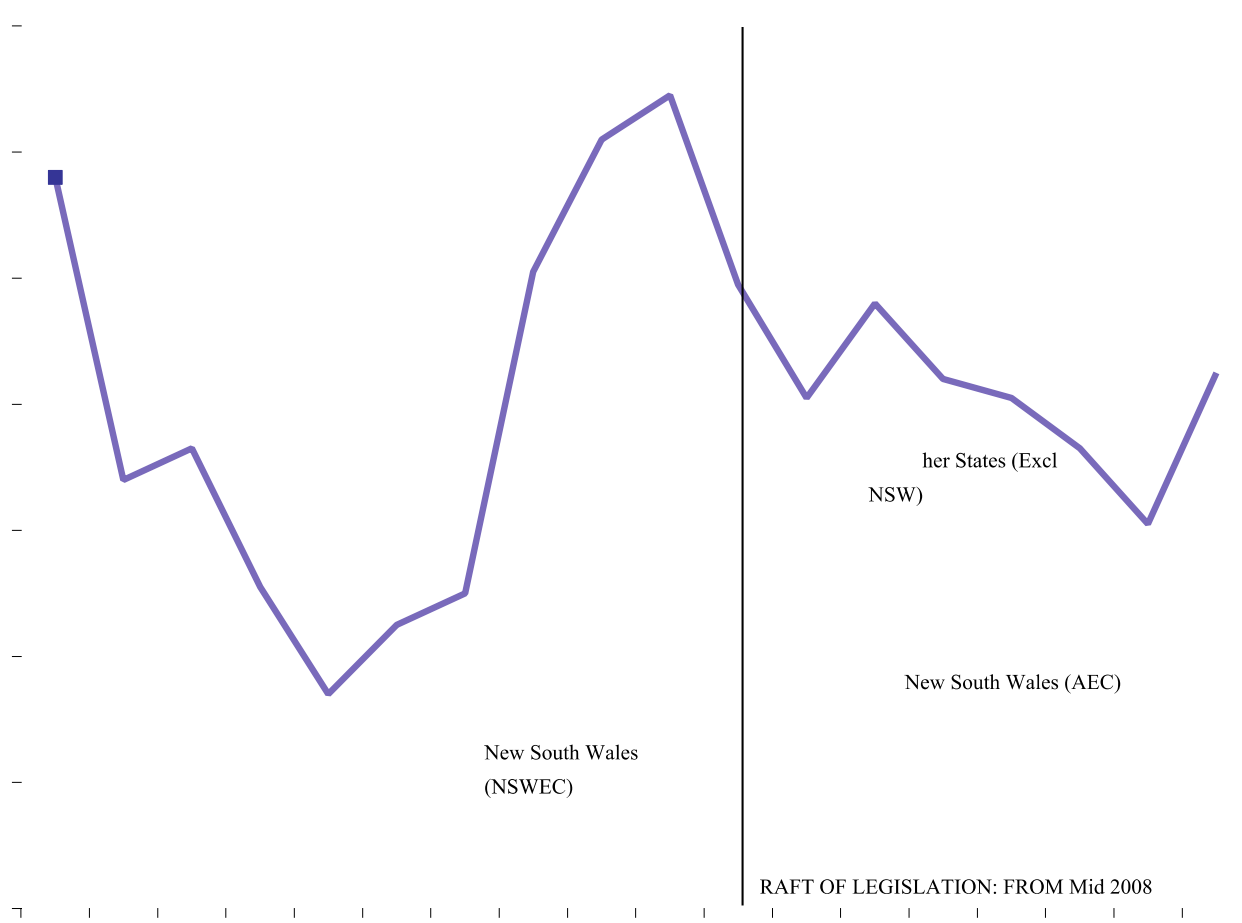

Banned Donations. Articulating the second plank of the framework, we argued that donations from problematic sources - namely, those likely to facilitate corrupt exchanges - undermine the quality of democracy. Based on this rationale, the New South Wales reforms banned donations from property developers, and gambling, alcohol and tobacco entities. To evaluate these reforms we would, ideally, like to observe how much money parties received from such sources. But the occurrence of illegal behaviour is difficult to observe as those involved conceal such activity. However, one way they might do so is by indicating their involvement in an industry that is not on the prohibited list. This strategy of concealment informs how we analyse the potential scale of the problem of donations from banned sources.

To classify the source of donations, we applied (with a few clarifying amendments) the industry classifications devised by the "Democracy4Sale" project to the registered names of corporate entities. ${ }^{44}$ In many cases, parties received money from entities that

\footnotetext{
${ }^{43}$ Analysis of the number of donations provides further support for this second, more positive interpretation. In particular, we can observe, based on the AEC data, a marked decline in the number of donations since the enhanced regulations were introduced.

${ }^{44}$ This project, which is owned and run by the Greens, classifies donors by industry sector.
} 
were active in industries that were similar to, without corresponding exactly to, those on the proscribed list - for example, from companies involved in "construction", which is similar to, but not the same thing as, "property development". And, further complicating matters, a business can shift its portfolio of activities while maintaining the same trading name. For our analysis, we identified donations from entities in the industries that we deemed to be functionally similar to those on the banned list. With the resulting list of entities, we cannot capture, in a direct and accurate way, donations from prohibited sources. But we can capture donations from what might be described as "suspicious" sources. Given the difficulty of observing actual illegal behaviour, this seems a practical way to estimate whether and how the reforms have impacted on donations from problematic sources.

Figure 4 below summarizes the change over time in the value of suspicious donations, as a percentage of the total value of donations reported by parties to the AEC. Comparing the pre-reform and post-reform contexts, these data suggest that there has been a noticeable decline in the number of such donations. This is a welcome development since it indicates a drop-off in the number of donations from sources that are potentially problematic. Moreover, if the number of actually illegal donations and thus the scale of the "black market" in political finance - is correlated with the number of suspicious donations, then the reforms may well have helped to address this issue. It should be noted, however, that a downward trend in the value of suspicious donations can also be detected in some other states and at the federal level, as the figure shows. But the trend is most pronounced in New South Wales, suggesting that the reforms in this state may have accelerated a broader trend. ${ }^{45}$

Figure 4: Value of Donations from Suspicious Sources as a Percentage of Value of All Donations (Reported by Parties to AEC, Above Threshold)

\footnotetext{
${ }^{45}$ In New South Wales there has been a 10.5 per cent decrease in the value of suspicious donations between the pre- and post-reform years. At the federal level there has been a 4.7 per cent decline; and similar trends can be observed in Queensland, Victoria and South Australia; but the value of such donations increased in Western Australia, Tasmania and the Northern Territory; and remained the same in the Australian Capital Territory.
} 


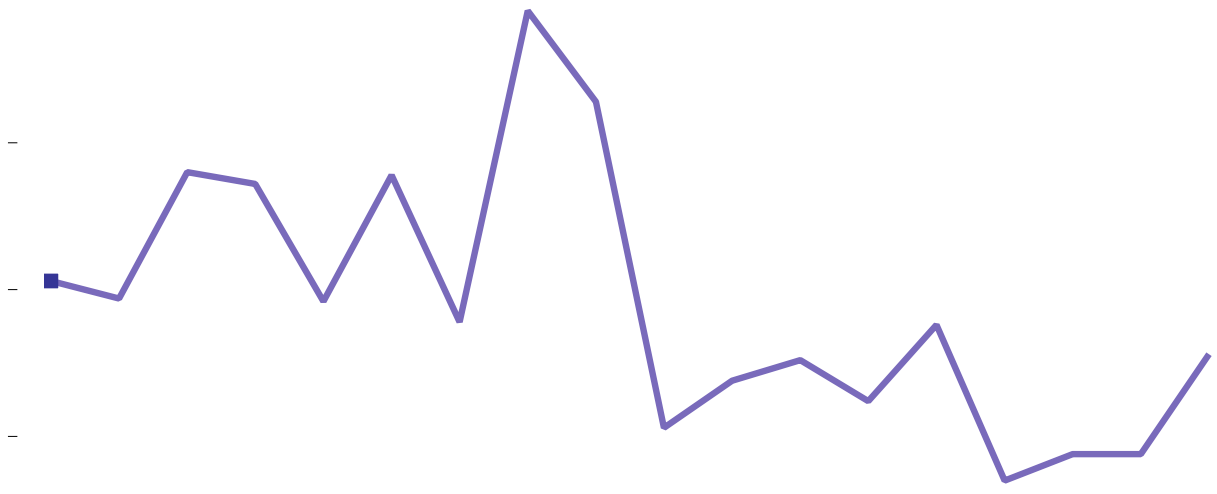

F LEGISLATION: FROM Mid 2008

Distribution of Donations among Parties. As the fourth plank of our normative framework, we considered the consequences of reform for the competitiveness of the party system. We argued that it was desirable for funds to be relatively evenly distributed among the political parties. On the other hand, a disproportionate flow of money to one party poses problems from a normative standpoint. Similarly, though perhaps less seriously, a disproportionate flow of money to the group of "insider" parties - a description that applies particularly to the ALP and the Coalition - is also problematic, for reasons that are highlighted in accounts of party system cartelization.

Assessed against these benchmarks, our data provide partial support for the contention that the reforms have improved the quality of democracy in New South Wales. On the positive side of the ledger, what was a significant financing gap between the ALP and the Coalition has narrowed over time. This suggests that, for the major parties, the reforms have made the market for funds more equal and more competitive.$^{46}$ The ALP had held the fundraising advantage over the Coalition so it has been the main loser in financial terms, which is particularly interesting when one considers that most of the new regulatory framework was enacted by Labor governments. ${ }^{47}$

At the same time, it appears that the reforms have not altered the relationship between the major and minor parties in the market for funds. This cleavage remains as pronounced as ever: the major parties continue to dominate while the minor parties lose

\footnotetext{
${ }^{46}$ This result corroborates findings presented by Rayner; see "More Regulated, More Level?".

${ }^{47}$ To explain this development, one might argue that the Labor government perhaps misperceived its interest. But perhaps a more convincing explanation, suggested by theoretical and empirical studies of political finance, is that left-leaning governments have a greater propensity to tighten political finance laws, due to their ideological heritage and anchoring in social groups that prioritise "equality" ahead of "liberty". On this argument, see Nwokora, "The Distinctive Politics of Campaign Finance Reform"; Christopher Witko, "Explaining Increases in the Stringency of State Campaign Finance Regulation, 1993-2002”, State Politics and Policy Quarterly, Vol. 7, 4 (2007), pp.369-393.
} 
out disproportionately, that is, even if we take account of their smaller size. These observations, which are consistent with the cartelization thesis, comport with previous research on political finance in Australia. What is more surprising, however, is that New South Wales compares unfavourably to most other jurisdictions in this respect, as Table 5 shows. ${ }^{48}$ Indeed, the flow of money to the major parties in the state, as a proportion of the total value of donations, has remained nearly constant over time. This suggests that while the reforms have altered the balance of financial power between the major parties, they have not altered the disparity between this class and the group of minor parties. ${ }^{49}$

Table 5: Proportion of Total Value of Donations to Major Parties (Reported by Parties to AEC, Above Threshold)

\begin{tabular}{|l|c|c|c|}
\hline Jurisdiction & Pre-Reform Years & Post-Reform Years & Change \\
\hline Federal & 94.9 & 91.8 & -3.1 \\
\hline ACT & 98.7 & 94.4 & -4.4 \\
\hline NSW & 99.2 & 98.9 & -0.3 \\
\hline Victoria & 99.0 & 95.4 & -3.5 \\
\hline Queensland & 98.0 & 94.9 & -3.1 \\
\hline SA & 95.3 & 92.1 & -3.2 \\
\hline WA & 94.9 & 91.9 & -3.1 \\
\hline Tasmania & 89.5 & 96.3 & 6.8 \\
\hline NT & 100 & 100 & 0.0 \\
\hline All Australia & 97.3 & 94.2 & -3.1 \\
\hline
\end{tabular}

Donations and Democracy in New South Wales. Table 6 below summarises the findings detailed above, and links these explicitly to the normative framework. Based on our empirical analysis, it can be strongly argued that the system of political financing in New South Wales has been improved, in terms of its likely impact on fairness and the quality of democracy in the state. Comparing the pre- and post-reform time periods, the size of the typical donation has decreased; the value of suspicious donations, which we use as a proxy for banned donations, has gone down; the total value of donations has declined; and the funding disparity between the ALP and the Coalition has been reduced. The overall picture that emerges, then, is a positive one. This analysis also raises some concerns, however. Crucially, it appears that the market for funds in New South Wales remains a stacked deck, with the major parties holding a massive advantage over the minor parties; and donors are underreporting more than before.

\footnotetext{
${ }^{48}$ To maintain consistency over the time period we study, we exclude the huge (personal) donations to the Palmer United Party (PUP), mainly at the federal level, in recent years.

49 Rayner reports a similar conclusion, finding that "spending and donation caps go some way towards narrowing the gulf between major and minor party budgets, but do far more to equalise the contest between the major parties"; see "More Regulated, More Level?", p.164.
} 
Furthermore, there are reasons to treat these results cautiously. Firstly, we cannot exclude the possibility that some of the money that seems to have disappeared from the New South Wales financing system might in fact have been funnelled into "third parties", that is, organisations which are not formally affiliated to political parties (but may be able to influence electoral outcomes through their activities). Secondly, we have not investigated whether the money that has been "squeezed out" of New South Wales might have found its way into other jurisdictions. ${ }^{50}$

Indeed, it is not inconceivable that the parties themselves may have encouraged donors in New South Wales to give to the party via other jurisdictions. This is a serious issue as it would raise questions about the overall effects of intensifying regulation in one jurisdiction without doing so across the nation. There seems no obvious regulatory solution to this problem within a jurisdiction: any attempt to restrict where donors can donate would inevitably infringe upon laws and norms relating to freedom of movement of persons and capital, and the freedoms that parties enjoy to decide how to organise their activities. ${ }^{51}$ So, to the extent that this is a problem, the solution must lie in greater regulatory alignment across jurisdictions.

Table 6: Political Finance Reform and the Quality of Democracy in New South Wales

\begin{tabular}{|l|c|c|c|}
\hline $\begin{array}{l}\text { Evaluative } \\
\text { criterion }\end{array}$ & $\begin{array}{c}\text { Indication of } \\
\text { improvement in } \\
\text { quality of } \\
\text { democracy }\end{array}$ & $\begin{array}{c}\text { Indication of } \\
\text { decline in } \\
\text { quality of } \\
\text { democracy }\end{array}$ & Actual observation \\
\hline $\begin{array}{l}\text { Unit size of } \\
\text { donations }\end{array}$ & Decrease & Increase & $\begin{array}{c}\text { Overall decrease, with } \\
\text { fluctuations }\end{array}$ \\
\hline $\begin{array}{l}\text { Donations from } \\
\text { problematic } \\
\text { sources }\end{array}$ & Decrease & Increase & Seemingly reduced \\
\hline $\begin{array}{l}\text { Total value of } \\
\text { donations }\end{array}$ & Decrease & Increase & $\begin{array}{c}\text { Overall decrease, with } \\
\text { fluctuations }\end{array}$ \\
\hline $\begin{array}{l}\text { Distribution of } \\
\text { funds among } \\
\text { political parties }\end{array}$ & $\begin{array}{c}\text { Levelling of } \\
\text { playing field' }\end{array}$ & $\begin{array}{c}\text { Greater } \\
\text { inequality }\end{array}$ & $\begin{array}{c}\text { Reduction of disparity } \\
\text { between major parties, but } \\
\text { not between the class of } \\
\text { 'major parties' compared to } \\
\text { 'minor parties' }\end{array}$ \\
\hline
\end{tabular}

\section{Conclusion}

In this study, we have examined the effects of the more stringent political finance regulation that has been introduced in New South Wales since 2008. Unlike other studies of the consequences of political finance regulation, we focused on their impact on the donors who are often the target of such reforms. More specifically, we analysed how these reforms have affected the pattern of donations in the state. To guide our

\footnotetext{
${ }^{50}$ See Issacharoff and Karlan, "The Hydraulics of Campaign Finance Reform".

51 See European Commission For Democracy Through Law (Venice Commission), "Guidelines on Political Party Regulation”, 25 October 2010.
} 
evaluation, we proposed an evaluative framework that links observations about the pattern of donations to expectations about the quality of democracy. This framework follows much of the scholarship on the quality of democracy by treating equality as the paramount democratic value. On this basis, we explained how four aspects of the pattern of donations - the size of a typical donation; the source of donations; the total value of donations and the distribution of money to the various political parties relate to the quality of democracy.

Using this framework, we examined historical trends in New South Wales, focusing on the periods before and after the introduction of the new regulations. We found strong, though somewhat qualified, support for the contention that these reforms have had a beneficial impact of the quality of democracy in the state. This analysis sheds light on the most prominent and debated episode of political finance reform in Australia, and it supports those who believed that these reforms would have generally beneficial effects. This study also contributes to the scholarship on political finance. Our framework provides a basis for assessing political finance regulation and reform in normative terms, and can be applied to other contexts. And our empirical findings support the argument, advanced by reform optimists, that regulations matter and their reform can improve how a financing system, and indeed a democracy, works in practice. 


\section{University Library}

\section{- M M N E R VA A gateway to Melbourne's research publications}

Minerva Access is the Institutional Repository of The University of Melbourne

Author/s:

Nwokora, Z;Anderson, M;Tham, J-C;Gauja, A;Mills, S;Miragliotta, N

Title:

Political Finance Regulation and Reform in New South Wales: Towards a Fairer System?

Date:

2019-03-01

Citation:

Nwokora, Z., Anderson, M., Tham, J. -C., Gauja, A., Mills, S. \& Miragliotta, N. (2019).

Political Finance Regulation and Reform in New South Wales: Towards a Fairer System?. AUSTRALIAN JOURNAL OF POLITICS AND HISTORY, 65 (1), pp.115-134. https:// doi.org/10.1111/ajph.12534.

Persistent Link:

http://hdl.handle.net/11343/286838 